\title{
A Comparative Study of Thumba Seed Bio Diesel
}

\author{
Shiv Lal ${ }^{1}$, V. K. Gorana ${ }^{1}$, N. L. Panwar ${ }^{2}$ \\ ${ }^{1}$ Department of Mechanical Engineering, Rajasthan Technical University, Kota, India; ${ }^{2}$ Department of Renewable Energy Sources, \\ College of Technology and Engineering, Maharana Pratap University of Agriculture and Technology, Udaipur, India. \\ Email: nlpanwar@rediffmail.com
}

Received February 23 ${ }^{\text {rd }}, 2011$; March 26 ${ }^{\text {th }}$, 2011; April 29 th $^{\text {th }} 2011$.

\begin{abstract}
Biodiesel is considering a clean-burning fuel produced from non edible vegetable oils, or animal fats. It is produced by transesterification of oils with short-chain alcohols or by the esterification of fatty acids. In the present context, biodiesel is an alternative eco friendly diesel fuel. Keeping this in view, an attempt has been made through the experiment of Thumba blended biodiesel on CI engine in laboratory and analyzes its properties and characteristic compare with other biodiesel oils. Five blends B05, B10, B15, B20 and B25 of thumba seed oil biodiesel were papered and it performance was evaluated with 7HP four-stroke diesel engine. The performance of thumba seed oil biodiesel were compared with biodiesel prepared by mustard, castor and Jatropha seed oil with same blends.
\end{abstract}

Keywords: Bio-Diesel, Thumba Oil, Blending, Engine Testing, Pollution

\section{Introduction}

Climate change is a global phenomenon that has a global scale impact. The current trend of climate change towards the warming of the globe has resulted in various changes in the geological, climatology, social, economi$\mathrm{cal}$, and biological processes worldwide. Temperature of the globe has increased due to various factors, but anthropogenic plays a major contribution through the heavy input of Greenhouse gases [1]. The emission from the vehicle is one the reason for global warming. So there is need to find out alternative of petroleum diesel. The biodiesel is one of replacement of diesel fuel. The biodiesel has been used to reduce petroleum consumption and pollutant emissions. Biodiesel is a non-toxic, sulphur-free, biodegradable, oxygenated and environment friendly alternate diesel fuel. Biodiesel (fatty acid alkyl esters) is an alternative diesel fuel derived from the reaction of vegetable oils or lipids and alcohol with or without the presence of a catalyst [2]. One of the important characteristic of biodiesel fuel is that its use does not require any significant modification in diesel engine [3].

One of the importance aspects of biodiesel is its biodegradability and being more environmental friendly than of the fossil fuels, resulting in less environmental impact upon accidental release to the environment. There are number of studies conducted by many researcher, scientist and entrepreneurs on safety, health and envi- ronmental effects of biodiesel emissions when biodiesel considered as a vehicular fuel [4-6]. In general combustion of biodiesel fuel in compression-ignition (CI) engines results in lower smoke, particulate matter, carbon monoxide and hydrocarbon emissions as compared to diesel combustion while the engine efficiency is little improved [7-9]. This may due to heating value, less calorific value, oxygen content, viscosity and higher density [10-12]. It was found that using biodiesel in diesel engines can reduce $\mathrm{HC}, \mathrm{CO}$ and $\mathrm{PM}$ emissions but NOx emission may increase $[13,14]$. In present study the biodiesel derived from thimba seed oil has been used. Five blends (B05, B10, B15, B20 and B25) were prepared and its performance were compared with biodiesel produced from mustard, castor and jatropha seed oil.

\section{Seed Preparation}

The action plan of India on biodiesel is targeted on Jatropha curcas Because it is a drought-resistant tree belongs to the Euphorbiaceae family, which is cultivated in all part of India.. Thumba seed oil is one which found in western Rajasthan (India) and it is very familiar to use in soap manufacturing industries. The Thumba is also a wild plant and does not produce any harmful effect like jatropha curcas seed if it comsumed by animal or hunman being. Thumba usually growing in rainy season and its seed available in summer season. Figure 1 shows the thumba and their seeds. 


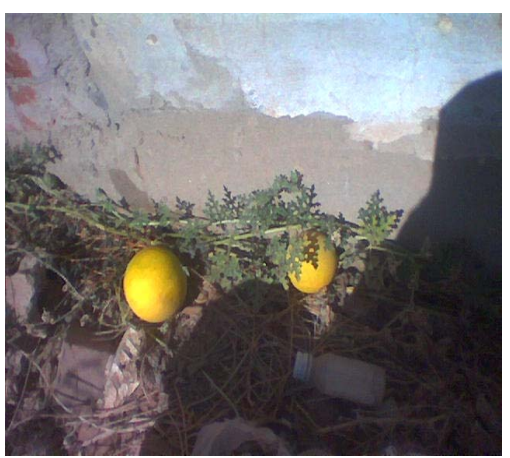

Stage 1

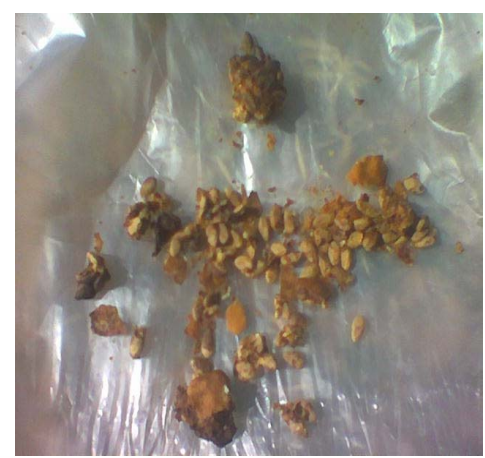

Stage 2

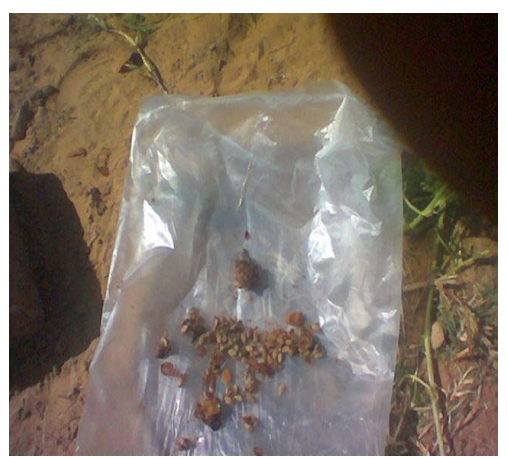

Stage 3

Figure 1. Thumba seed.

\section{Experimental Set-up}

The performace and suitability of thumba seed oil biodiesel a four-stroke single cylinder diesel engine having brake power 7 bhp at $1500 \mathrm{rpm}$, the cylinder stroke length and bore diameter are $110 \mathrm{~mm}$ and $87.5 \mathrm{~mm}$ respectively was used. The orifice diameter $25 \mathrm{~mm}$ and coefficient of discharge is 0.64 . The brake drum type dynamometer of $0.155 \mathrm{~m}$ drum diameter is used for applying the load. Maximum load capacity of this engine is $20 \mathrm{~kg}$. The experimental set is shown in Figure 2. In which 1-2-3-12 is an air circuit. In this circuit air passed through air filter (2) and goes to the engine through engine inlet valve. For the measurement of air supply to the engine a U-tube manometer (4) was used. Air compressed by the piston in compression stroke at the end of compression combustion starts and after complete combustion in power stroke; the combusted gases goes through the filter in the atmosphere. Here 10-8-7-11-6 is a fuel circuit for bio-diesel supply. Whereas 10 is a fuel tank, 9 is a graduated trans- parent glass tube which used to measure the fuel consumption in engine per second, 8 is a fuel filter, 7 is a fuel pump and 6 is multi-point injector. For measuring of brake power a brake drum type dynamometer was used at the engine which shows in label 15 (drum) and 16 (belt and weight spring). Another most important circuit is the cooling circuit in which 14 is the source or sink of water supply to the engine where 13,19 , are the pump and three way valve respectively.

\section{Results and Discussion}

The variation of brake specific fuel consumption with respect to break horse power is presented in Figure 3. Five blends (B05, B10, B15, B20 and B25) were prepared with four different biodiesel namely, mustard, castor, thumba and jatropha. For all blends tested, brake specific fuel consumption is found to decrease with increase in BHP. Blend, B10 of all biodiesel yield better results as compared to other blends.

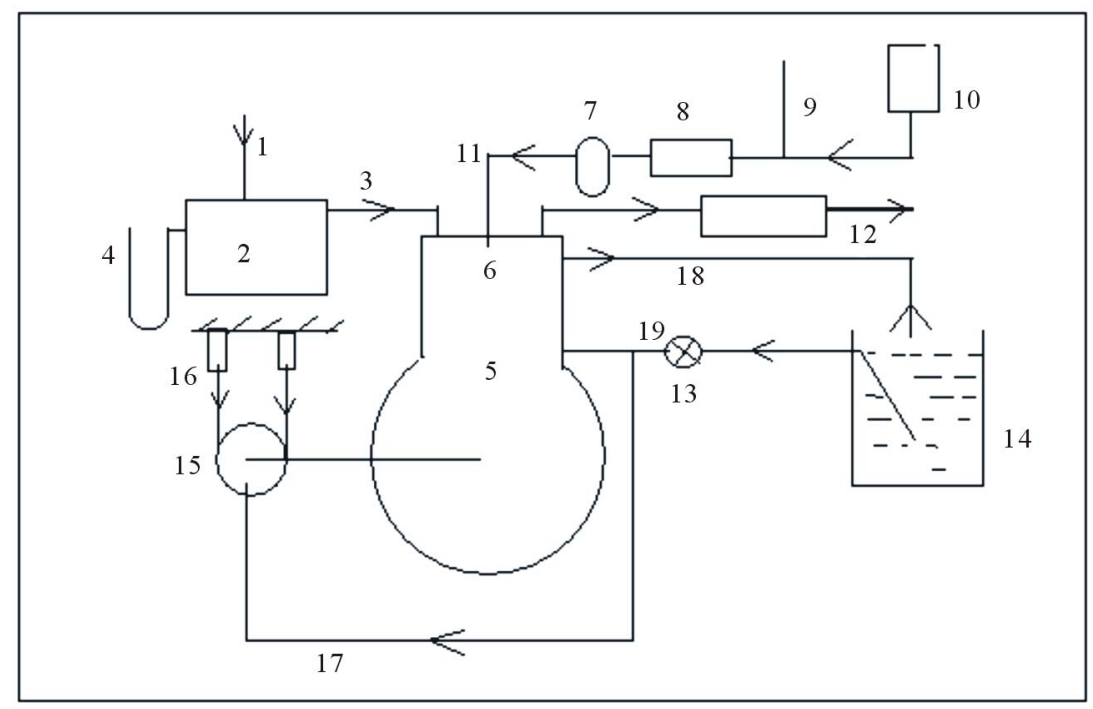

Figure 2. Experimental set-up. 


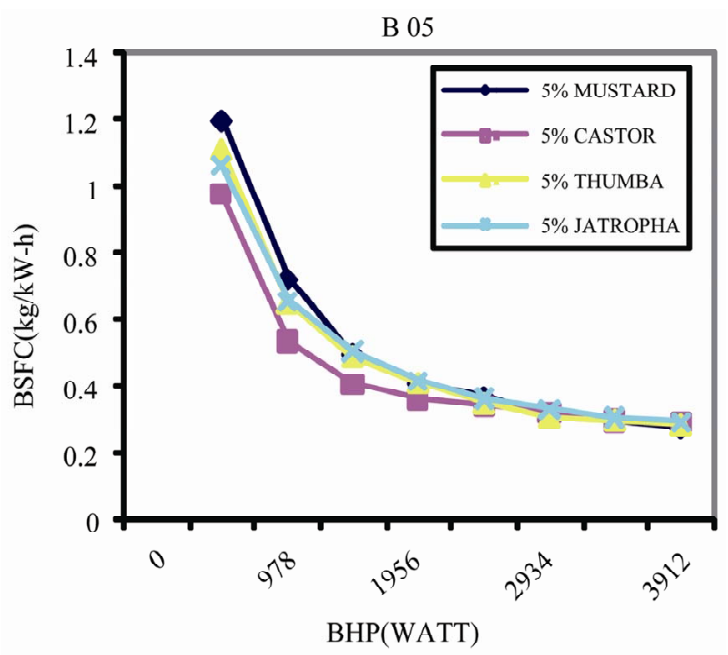

(a)

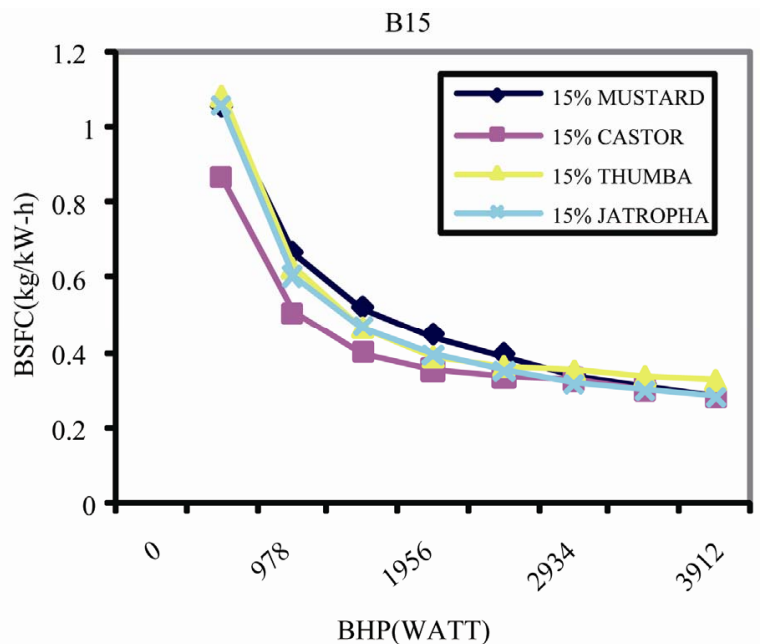

(c)

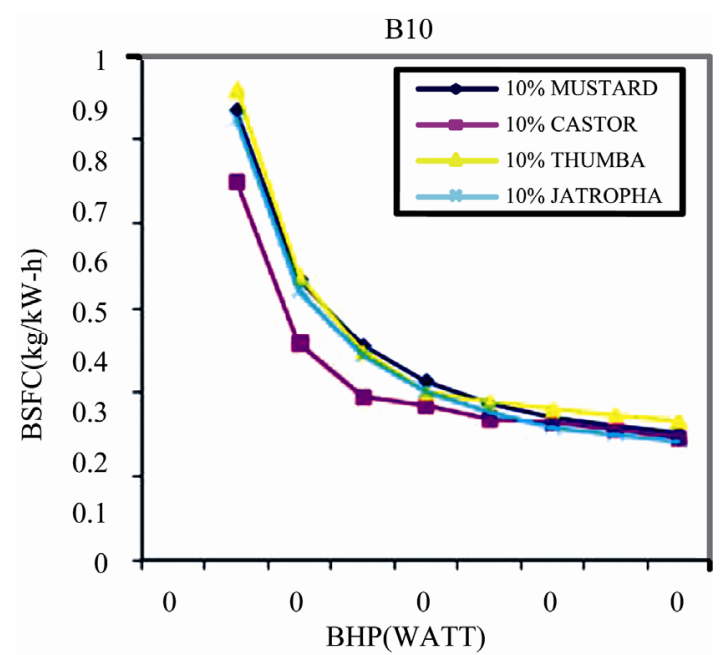

(b)

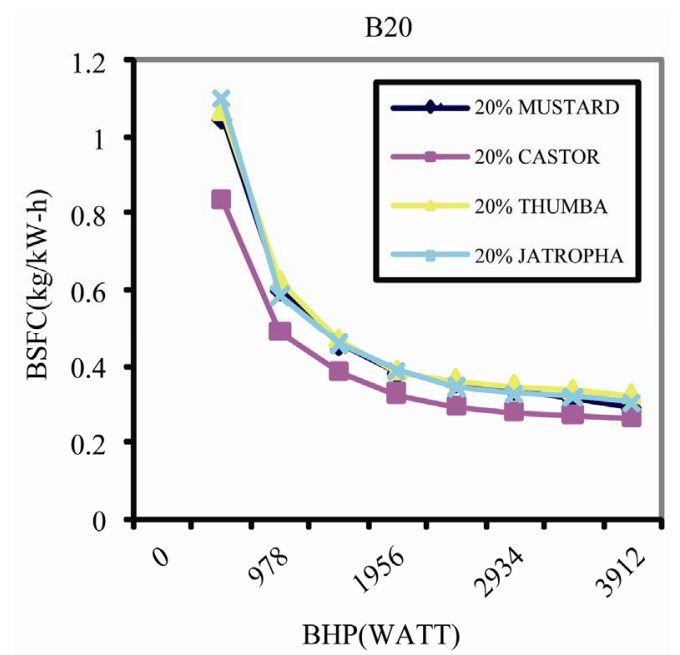

(d)

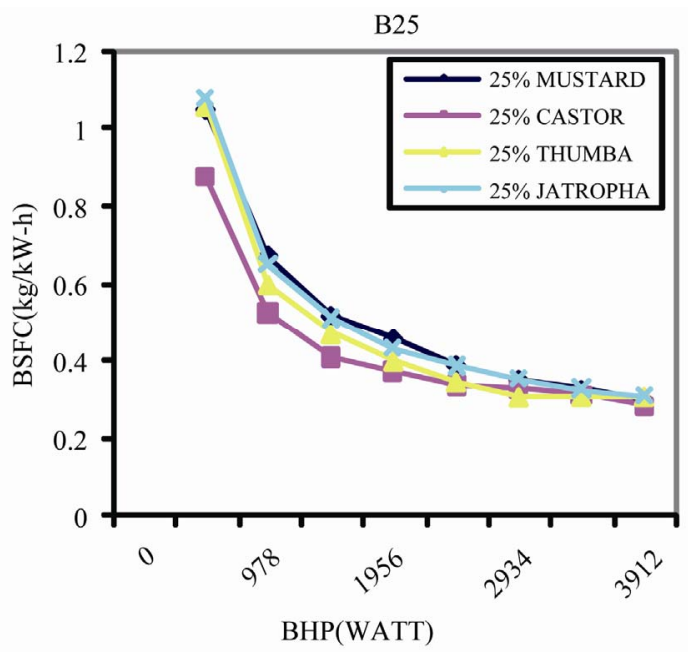

(e)

Figure 3. Break specific fuel consumption with break horse power. 
Figure 4 reveals the variation of mechanical efficiency with respect to BHP for different blends. In all cases, brake thermal efficiency was having tendency to increase

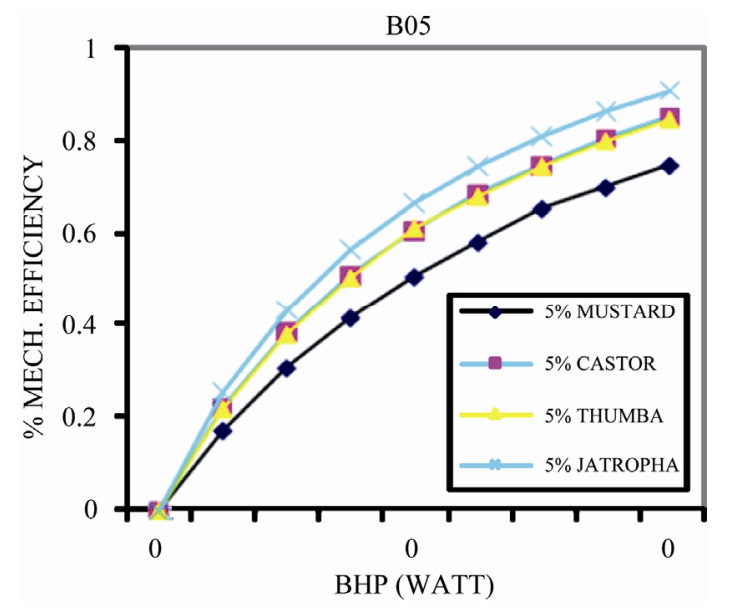

(a)

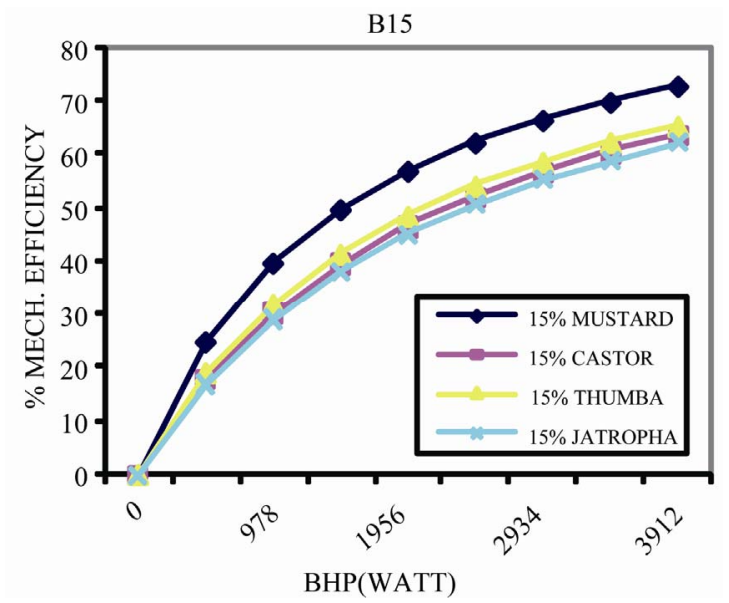

(c) with increase in applied BHP. Thumba seed biodiesel blends (B20) shows comparable mechanical efficiency with other biodiesel.

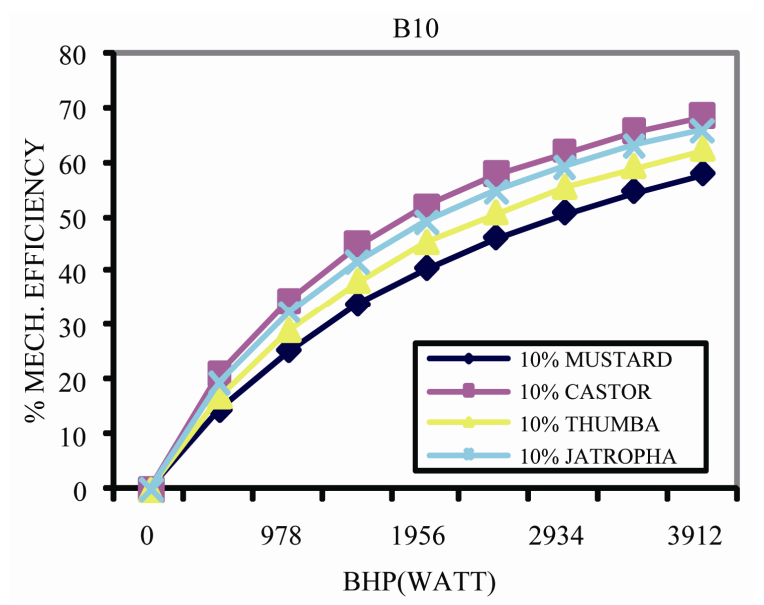

(b)

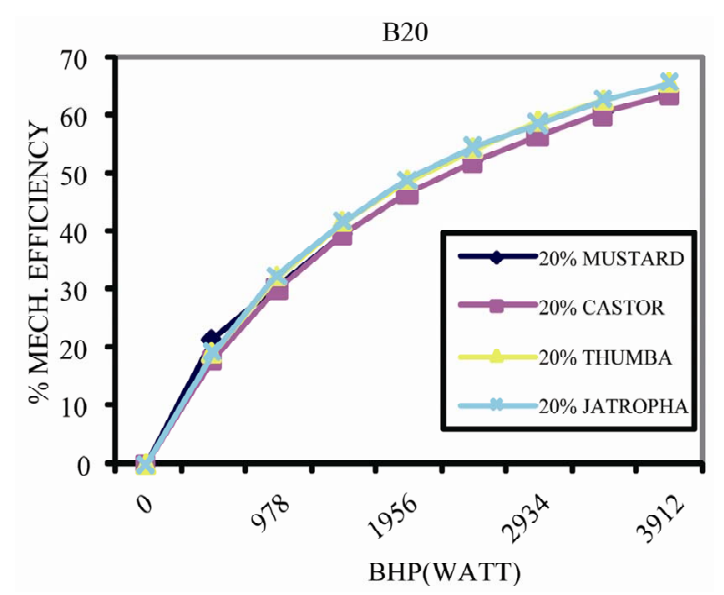

(d)

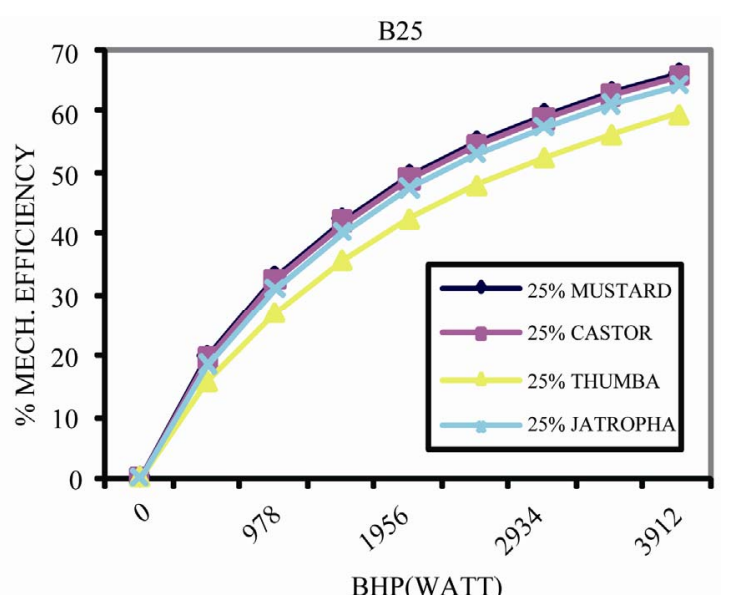

(e)

Figure 4. Mechanical efficiency with BHP. 
ISFC of thumba seed biodiesel is lowest at B25 for all loads and it is comparable for other blending to corresponding load as illustrated in Figure 5.

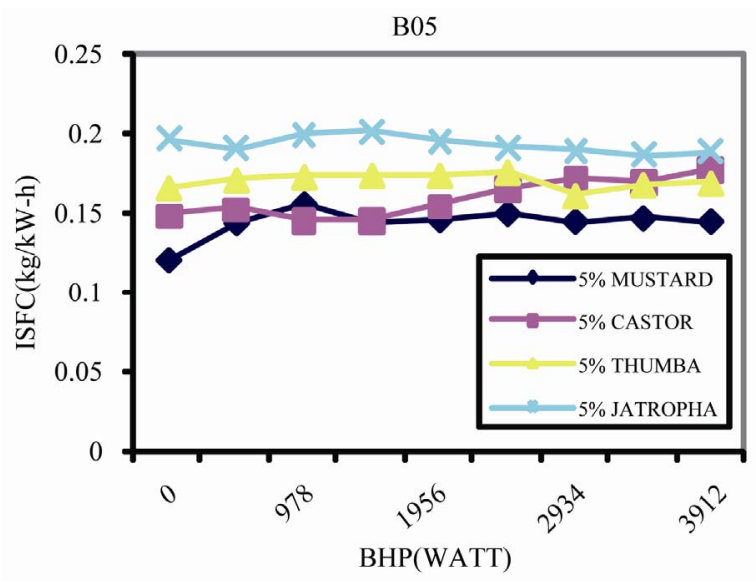

(a)

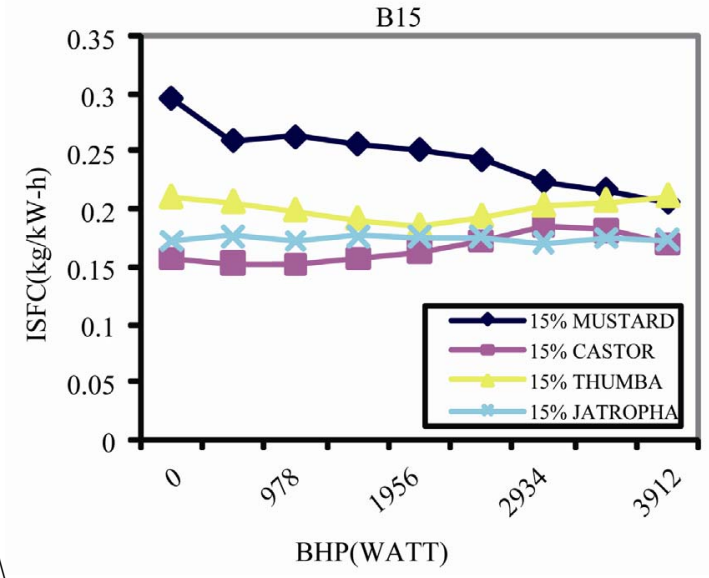

(c)

\section{Conclusions}

The major problem associating with diminishing petroleum reserves and the increasing attentiveness of envi

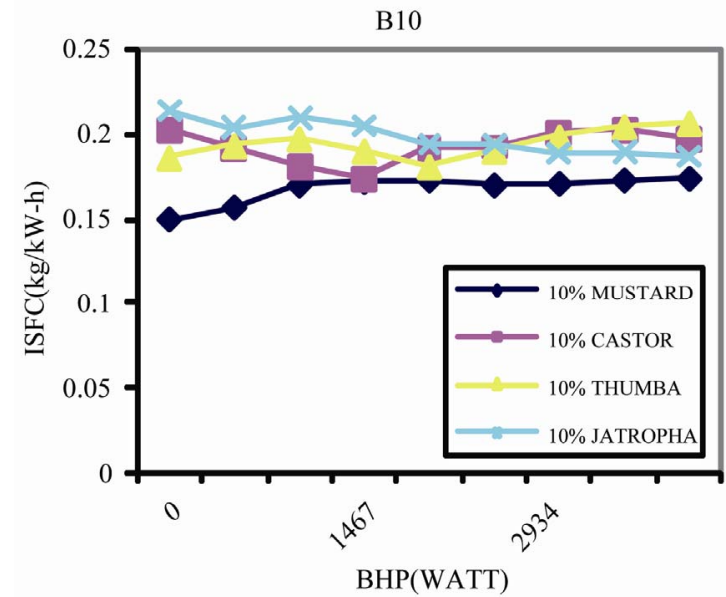

(b)

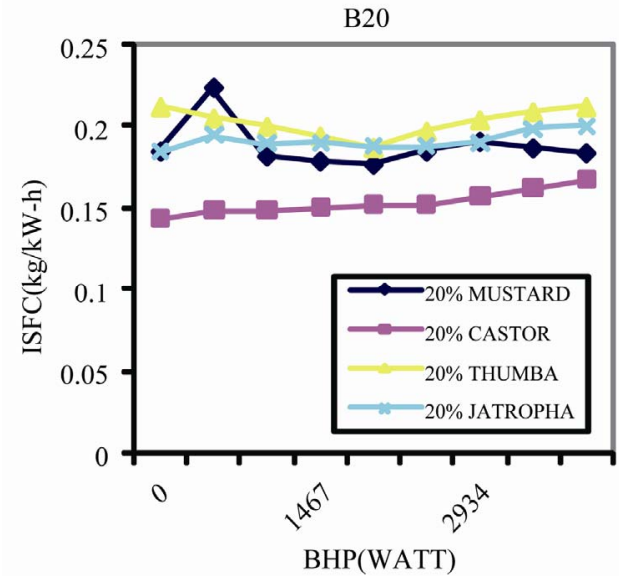

(d)

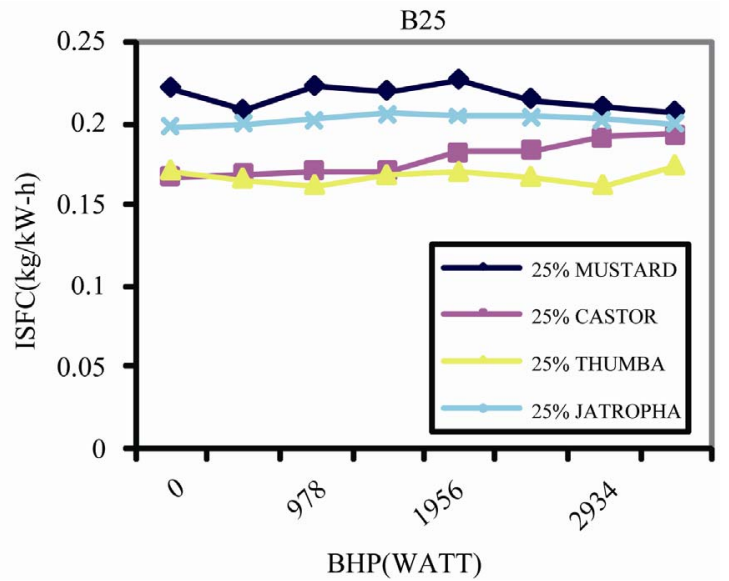

(e)

Figure 5. isfc v/s bhp. 
ronmental pollution from fossil petroleum fuel emissions have led to the urge to find renewable alternative fuels as a substitute for petroleum based fuel. Biodiesel is a clean burning fuel that is renewable and biodegradable. Biodiesel is found better substitute for petroleum diesel and also most advantageous over petro-diesel for its environmental friendliness. The quality of biodiesel fuel was found to be considerable for its doing well use on compression ignition engines and ensuing replacement of non-renewable fossil fuels. Biodiesel produce from thumba seed oil also yield comparable results with petroleum diesel.

\section{REFERENCES}

[1] J. S. Pechsiri, A. Sattari, P. G. Martinez and L. Xuan, “A Review of the Climate-Change-Impacts' Rates of Change in the Arctic", Journal of Environmental Protection, Vol. 1, No. 1, 2010, pp. 59-69. doi:10.4236/jep.2010.11008

[2] Y. Zhang, M. A. Dube, D. D. McLean and M. Kates, "Biodiesel Production from Waste Cooking Oil: 1. Process Design and Technological Assessment," Bioresource Technology, Vol. 89, No. 1, 2003, pp. 1-16. doi:10.1016/S0960-8524(03)00040-3

[3] N. L. Panwar, H. Y. Shrirame, N. S. Rathore, S. Jindal and A. K. Kurchania, "Performance Evaluation of a Diesel Engine Fueled with Methyl Ester of Castor Seed Oil”, Applied Thermal Engineering, Vol. 30, No. 2-3, 2010, pp.245-249.doi:10.1016/j.applthermaleng.2009.07.007

[4] J. S. Gaffney and N. A. Marley, "The Impacts of Combustion Emissions on Air Quality and Climate from Coal to Biofuels and Beyond", Atmos Environ, Vol. 43, No.1, 2009, pp. 23-36. doi:10.1016/j.atmosenv.2008.09.016

[5] H. Huo, Y. Wu and M. Wang, "Total Versus Urban: Well-to-Wheels Assessment of Criteria Pollutant Emissions from Various Vehicle/Fuel Systems”, Atmos Environ,Vol. 43, No. 10, 2009, pp. 1796-1804. doi:10.1016/j.atmosenv.2008.12.025

[6] G. Karavalakis, S. Stournas and E. Bakeas. "Effects of Diesel/Biodiesel Blends on Regulated and Unregulated Pollutants from a Passenger Vehicle Operated over the European and the Athens Driving Cycles," Atmos Envi- ron, Vol. 43, No. 10, 2009, pp. 1745-1752. doi:10.1016/j.atmosenv.2008.12.033

[7] S. Jindal, B. P. Nandwana and N. S. Rathore, "Comparative Evaluation of Combustion, Performance, and Emissions of Jatropha Methyl Ester and Karanj Methyl Ester in a Direct Injection Diesel Engine”, Energy Fuels, Vol. 24, No. 3, 2010, pp. 1565-1572. doi:10.1021/ef901194z

[8] M. Zheng, M. C.Mulenga, G. T. Reader, M. Wang, D. S. K. Ting and J. Tjong, "Biodiesel Engine Performance and Emissions in Low Temperature Combustion”, Fuel, Vol. 87, No. 6, 2008, pp. 714-722. doi:10.1016/j.fuel.2007.05.039

[9] A. K. Agarwal and K. Rajamanoharan, "Experimental Investigations of Performance and Emissions of Karanja Oil and Its Blends in a Single Cylinder Agricultural Diesel Engine”, Applied Energy, Vol. 86, No. 1, 2009, pp. 106-112. doi:10.1016/j.apenergy.2008.04.008

[10] Y. D. Wang, T. Al-Shemmeri, P. Eames, J. Mcmullan, N. Hewitt and Y. Huang. "An Experimental Investigation of the Performance and Gaseous Exhaust Emissions of a Diesel Engine using Blends of a Vegetable Oil”, Applied Thermal Engineering, Vol. 26, No. 14-16, 2006, pp. 16841691. doi:10.1016/j.applthermaleng.2005.11.013

[11] D. Wang, C. Zhang and Y. Wang. "A Numerical Study of Multiple Fuel Injection Strategies for NOx Reduction from DI Diesel Engines”, International Journal of Green Energy, Vol. 4, 2007, pp. 453-470. doi:10.1080/15435070701465912

[12] Y. F. Lin, Y. P. G. Wu and C. T. Chang, "Combustion Characteristics of Waste-Oil Produced Biodiesel/Diesel Fuel Blends”, Fuel, Vol. 86, No. 12-13, 2007, pp. 17721780. doi:10.1016/j.fuel.2007.01.012

[13] S. Puhan, N. Vedaraman, G. Sankaranarayanan and B. V. B. Ram, "Performance and Emission of Mahua Oil (Madhuca Indica Oil) Ethyl Ester in a 4-Stroke Natural Aspirated Direct Injection Diesel Engine,” Renewable Energy, Vol. 30, No. 7, 2005, pp. 1269-1278. doi:10.1016/j.renene.2004.09.010

[14] N. L. Panwar, H. Y. Shrirame and B. R. Bamniya. " $\mathrm{CO}_{2}$ Mitigation Potential from Biodiesel of Castor Seed Oil in Indian Context,” Clean Technologies and Environmental Policy, Vol. 12, No. 5, 2010, pp. 579-582. doi:10.1007/s10098-009-0269-5 